\title{
Duhovna strana izlječenja - nadnaravno čudo ili spontana remisija
}

\author{
1 Aleksandar Racz \\ 1 Jadranka Pavić \\ 2 Vlado Čutura \\ 1 Zdravstveno veleučilište Zagreb \\ 2 Glas Koncila
}

\section{Sažetak}

Rad je usmjeren na prikaz primjera duhovne strane izlječenja u kojoj postoje različiti pristupi znanstvenika u objašnjenju iznenadnih izlječenja te utjecaja molitve na ishod bolesti. Čudesna izlječenja predstavljaju izazov znanstvenicima u traženja dokaza koji mogu pružiti odgovor na pitanje utječu li zagovorničke molitve na povoljni ishod liječenja te mogu li se pojedini slučajevi objasniti medicinskim terminom spontane remisije. Polazna pretpostavka nekih znanstvenika glasi da je moguć pozitivan utjecaj zagovorničke molitve na izlječenje oboljelih, dok dio znanstvenika kritičkom analizom tih istraživanja ne nalazi opravdanja za prikazane rezultate. Na temelju raspoloživih rezultata dosad provedenih istraživanja nije moguće donijeti zaključak koji bi išao u smjeru potvrđivanja ili odbacivanja mogućeg utjecaja zagovorničke molitve na ishod liječenja, iako postoji mnogo više studija koji takvu vezu ne dokazuju, pogotovo među onima koje su provedene po metodologiji kontroliranoga kliničkog pokusa. Međutim, postoje brojni dokazi o pozitivnim ishodima među ispitanicima koji su sami aktivno molili za svoje zdravlje, od smanjenja komplikacija liječenja do smanjenja letalnih ishoda. Navedeni rezultati upućuju na to da molitva i duhovnost imaju svoje mjesto u inte- griranoj skrbi za pacijenata kao tjelesnom, ali i duševnom i duhovnom biću. Istovremeno, pojedinačni slučajevi čudesnog izlječenja među hodočasnicima ili među osobama koje su osobno intenzivno molile za vlastito izlječenje, ponajprije u Lourdesu i Međugorju, upućuju na to da je s medicinskog aspekta riječ o vrlo zanimljivom fenomenu čije pomno znanstveno istraživanje ima svoju vrijednost.

Ključne riječi: čudesno izlječenje, duhovnost, liječenje molitvom

Datum primitka: 14.06.2015.

Datum prihvaćanja: 16.02 .2016 .

Adresa za dopisivanje:

Dr. sc. Aleksandar Racz, prof. v. š.

Zdravstveno veleučilište

Mlinarska 38, Zagreb, tel.: +385 (0)1 4595722

E-pošta: aleksandar.racz@zvu.hr

Zahvala:

Autori rada najtoplije zahvaljuju p. A. Bobašu, svećeniku dominikancu na svesrdnoj i stručnoj pomoći u izradi rada.

\section{Uvod}

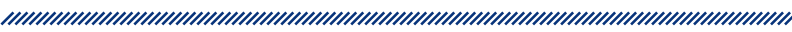

Duhovnost kao složeni i multidimenzionalni dio ljudskog iskustva usko je povezana s fenomenom zdravlja, bolesti, liječenja i izlječenja. Brojna su znanstvena istraživanja kroz povijest potvrdila povezanost duhovnosti i poboljšanja zdravlja. Prva istraživanja na području 
povezanosti duhovnosti i zdravlja počela su u 19. stoljeću s oko 250 empirijskih studija ${ }^{1}$. Međutim, tek u šezdesetim godinama 20. stoljeća znatno se povećao broj empirijskih studija koje su usmjerene na istraživanje povezanosti duhovnosti i zdravlja.

U priručniku „Handbook of Religion and Health" obrađeno je više od 1200 znanstvenih studija i 400 znanstvenih prikaza koji su bili usmjereni na ljudsko zdravlje putem psihoneuroimunoloških mehanizama. $U$ analizi studija i prikaza potvrđena je povezanost između duhovnosti i religioznosti te više razine zdravlja. Ova povezanost potvrđena je na području srčanožilnih bolesti, bolesti imunološkog sustava, psihičkih bolesti, prevencije ovisnosti (alkoholizma, pušenja), prevencija suicida te suočavanja s kroničnim bolestima (multipla skleroza, maligne bolesti) $)^{2,3}$. Duhovnost je tek posljednjih dvadesetak godina na području medicine postala iznimno istraživan fenomen koji početkom 21. stoljeća u većem broju zemalja nalazi svoje mjesto i u direktnoj kliničkoj primjeni kroz programe koji imaju za cilj integrirati duhovne potrebe i potencijale pacijenata s terapijskim procesom. Vjera u ozdravljenje uplivom nadnaravne sile kao uslišenje upućenih molitva i vjere duboko je ukorijenjena u kršćansku, posebice katoličku tradiciju. Za praktične vjernike molitva predstavlja duboko osoban, religiozan čin, u kojem se vjernici izgovaranjem određenog teksta za ozdravljenje usrdno obraćaju Bogu. Moliti bolesniku znači razgovarati s Bogom i zadržavati se $s$ njim, zahvaljivati, klanjati se, iznositi svoja razmišljanja i osjećaje, moliti ga nešto i davati zadovoljštinu. „Molitva pretpostavlja vjeru u osobnog i nazočnog Boga, kao i uvjerenje da će Bog uslišati molitelja.“4 U Hrvatskoj nema opsežnih znanstvenih istraživanja o odnosu duhovnosti i ozdravljenja. $U$ istraživanju religioznog iskustva na osnovi samoiskaza na uzorku od 2220 ispitanika koje je provela Marinović Bobinac ${ }^{5} 14 \%$ ispitanika doživjelo je iskustvo ozdravljenja koje je povezano s religijskim iskustvom. Ameling ${ }^{6}$ donosi podatak da čak $82 \%$ Amerikanaca vjeruje da osobna molitva može izliječiti ozbiljne bolesti, daljnjih $73 \%$ vjeruje da molitvom za druge i njima može doći do izlječenja te bi čak $64 \%$ američkih bolničkih pacijenata željelo da liječnici s njima mole za njihovo ozdravljenje. Pri tome se molitvom češće koriste vjernici, starije osobe, žene, siromašniji, loše educiraniji i kronični bolesnici u odnosu na druge kategorije ispitanika ${ }^{7}$. Molitva je $i$ inače vrlo prisutna u svakodnevnom životu, što potvrđuje podatak da se čak $75 \%$ Amerikanaca moli najmanje jednom tjedno ${ }^{8}$. $\mathrm{S}$ obzirom na navedeno, razumljivo je da se molitva smatra i dijelom komplementarne medicine i prilikom klasifikacije uobičajeno se uvrštava u tzv. mind - body tehnike ${ }^{9}$. Kaptchuk i sur. ${ }^{10}$ svrstavaju molitvu u područje spiritualnog iscjeljenja. $U$ istraživanju na uzorku od 31044 odraslih Amerikanaca Barnes i sur. ${ }^{11}$ potvrdili su da je $62 \%$ ispitanika u zadnjih godinu dana primjenjivalo neku od metoda ili tehnika komplementarne ili alternativne medicine. Kad se međutim odvoje one tehnike koje uključuju molitvu, postotak onih koji su se koristili nekom komplementarnom metodom smanjuje se na $36 \%$. Isto istraživanje među deset najpopularnijih tehnika komplementarne medicine u samom vrhu izdvaja njih tri koje uključuju molitvu, i to: individualnu molitvu za samog sebe, zagovorničku molitvu za drugog te sudjelovanje u grupnim molitvenim susretima. Kroz molitve se očekuje događaj čudesnog izlječenja.

\section{Čudesna izlječenja}

Različiti pristupi čudesnim izlječenjima potječu iz razlika u razumijevanju uzročnih čimbenika, koncepata prirode i odnosa između Boga i prirode. Unatoč mnogim skeptičnim argumentima, većina ljudi (oko $70 \%$ ) u suvremenim zapadnim društvima dijele vjeru u čuda i milijuni bolesnih ljudi hodočaste u svetišta tražeći njihovu pojavu ${ }^{12}$. Postoje brojne definicije čuda, jer je teško predstaviti detaljan i jedan općeprihvaćen pristup. Riječ „,̌̌udo“ dolazi od latinske riječi miraculum, što je izvedeno iz mirari, a znači nešto prekrasno. Čudo je, po definiciji, izvanredan događaj koji nadilazi prirodne sile i običan prirodni red ${ }^{13}$. Dakle, najopćenitije epistemološki, karakterizacija čuda predstavlja događaj koji izaziva divljenje i na neki je način neobičan ili suprotan našim očekivanjima ${ }^{14}$. Filozof Hume čudesna izlječenja opisuje kao nasilno kršenje prirodnih zakona, pri čemu je dio tih neobičnih ozdravljenja dokumentiran, proučen i prepoznat, a tek su vrlo mali broj i priznale službene crkvene institucije ${ }^{15}$. Slučajeve neočekivanih izlječenja koji se na današnjem stupnju znanja medicine ne mogu objasniti poznatim patofiziološkim procesima nazivamo „čudom“ ili, u vjerskim hodočasničkim središtima, „ozdravljenjem“.

U Bibliji ${ }^{16}$ opise izlječenja kao odgovor na vjeru i molitvu nalazimo na više mjesta i vrlo su važna za razumijevanje ishodišta nadanja koje pacijenti u katoličkoj tradiciji polažu u snagu molitve. Naime, još je svojim apostolima Isus zapovjedio „Bolesne liječite“ (Mt 10:8) uz obećanje: „Na nemoćnike će ruke polagati i bit će im dobro" (Mk 16:18). 
Opise nadnaravnih izlječenja nalazimo na više mjesta u Bibliji:

- ...sjedio je kraj puta slijepac prosjak Bartimej.. Čim ču da je to Isus Nazarećanin, poče vikati: 'Isuse, Sine Davidov, smiluj mi se!' Isus zovnu slijepca i reknu mu:' Uzdaj se! Ustani, zove te!' On baci svoj ogrtač, skoči i dođe k Isusu. Isus ga upita: 'Što hoćeš da ti učinim?' 'Učitelju, želim progledati!' odgovori mu slijepac. 'Hajde - reče mu Isus - tvoja te vjera spasila (ozdravila)!' Smjesta progleda i uputi se za Njim. (Mk 10:46-52)

- Idi! Neka ti bude kako si vjerovao! I njegov sluga ozdravi u isti čas. (Matej 8:13)

- Vjerujete li da to mogu učiniti? Da, Gospodine - odgovore mu. Tada im se dotače očiju i reče: „Neka vam bude prema vašoj vjeri!“I otvoriše im se oči... (Mt 9:28,29)

- Ovi ga zamoliše da im dopusti samo dotaknuti se skuta Njegove haljine. I ozdraviše svi koji ga se dotakoše. (Mt 14:34-36)

- Kako ga zbog mnoštva naroda ne mogoše donijeti pred Njega, skinuše krov nad mjestom gdje je bio Isus te kroz otvor spustiše postelju na kojoj je ležao uzeti. Isus vidje njihovu vjeru i reče uzetome: "Zapovijedam ti, ustani, uzmi svoju postelju i hajde kući svojoj!“ On ustade, smjesta uze svoju postelju i iziđe naočigled sviju. (Mk 2:4-12)

- Kad je ulazio u neko selo, iziđe mu u susret deset gubavaca...i počeše vikati: „Isuse, Učitelju, smiluj nam se!“ ... I očistiše se dok su odlazili... Ni jedan se ne nađe da se vrati i Bogu zahvali, osim ovoga tuđina! I reče mu: „Ustani i hajde, tvoja te vjera spasila!“" (Lk 17:11-19)

Opisanim ozdravljenjima u Svetim spisima u novije doba svjedočimo kao ključnim dokazima u postupku beatifikacije i kanonizacije više od 600 svetaca u razdoblju od 17. do 20. stoljeća koji su proglašavani svetima na temelju dokaza o čudu koji se u 95 \% slučajeva odnose na fizička izlječenja ${ }^{17,18}$. Vatikanska Kongregacija za kauze svetaca proglasila je 347 dekreta o čudima između 1983. i $2004 .{ }^{19}$ Zadnje u nizu je čudo izlječenja redovnice Marie Simon-Pierre koja je ozdravila u trenutku kada se spremala napustiti službu u rodilištu zbog Parkinsonove bolesti koja joj je otežavala kretanje, a ozdravila je preko noći nakon što se dva mjeseca u molitvama obraćala pokojnom papi Ivanu Pavlu Drugom ${ }^{20}$. Vjera u nadnaravno, paranormalno izlječenje vrlo je često zadnja nada oboljelima od kroničnih ili neizlječivih bolesti od postanka ljudskog roda. Posebno je to naglašeno u no- vije vrijeme kod onih koji su razočarani odnosom prema njima kao pacijentima u dehumaniziranom, tehnološkom zdravstvenom sustavu orijentiranom na liječenje izlječivih nauštrb ignoriranja neizlječivih ${ }^{21}$.

\section{Marijanska svetišta i čudesna izlječenja}

Čudesna izlječenja najčešće se opisuju u brojnim odredištima hodočašća kao mjestima Marijanskih ukazanja od Beaurainga u Belgiji, preko Kereziha i La Salette u Francuskoj, Fatime u Portugalu, Czestohowa u Poljskoj, Guadalupe u Meksiku, Garabandala u Španjolskoj, Knocka u Irskoj, Walshingtona u Engleskoj, La Vanga u Vijetnamu i Kibeha u Ruandi do Međugorja u Bosni i Hercegovini. Najbolje su dokumentirani slučajevi ozdravljenja u Lourdesu ${ }^{22}$, najvećem kršćanskom svetištu na svijetu, u kojima su zabilježena neobjašnjiva ozdravljenja od najtežih bolesti. Prema crkvenim dokumentima, 1858. godine četrnaestogodišnja djevojčica Marie-Bernadette Soubirous (sada sveta Bernardica) iz Lourdesa kraj špilje je doživjela susret s Majkom Božjom²3. Dvanaestog se dana po ukazanju dogodilo prvo ozdravljenje nakon što je jedna žena svoju paraliziranu ruku oprala $u$ vodi iz špilje te je time započela era najmoćnijega kršćanskog svetišta na svijetu, ali i svjedočanstava o čudesnim ozdravljenjima. Fama o Lourdesu pojačala se prvim izlječenjem 1875. godine kada je jedan slijepac nakon pranja u vodi iz špilje progledao. Statistike pokazuju da je do današnjih dana Lourdes zabilježio nekih 200 milijuna posjeta, dok je Association medicale internationale de Lourdes $^{24}$ zabilježio i proučio oko 4000 ozdravljenja od raznih bolesti kao što su razna sijela tuberkuloze, bilateralna sljepoća, Addisonova bolest, Hodgkinova bolest, reumatoidni spondilitis, amiotrofična lateralna skleroza, osteomijelitis, osteoperiostitis, Ewingov sarkom, multipla skleroza, hemiplegije i paraplegije, tuberkuloza, bolesti kože itd. ${ }^{25}$ Nadalje, marijansko svetište u Međugorju u Bosni i Hercegovini poznato je u svijetu po fenomenu koji se dogodio 1984 . godine, kada se grupi djece na brdu u Bijakovićima ukazala Majka Božja. Svetište Međugorje dosad je posjetilo više od 20 milijuna hodočasnika, a veći je dio njih molitvom tražio ozdravljenje. Samo u prvih dvadeset godina od ukazanja u Marijinu svetištu Međugorju zaprimili su 445 prijava o čudesnim tjelesnim ozdravljenjima za koje Centar Mir Međugorje navodi da je riječ o dobro ili sla- 
bije dokumentiranim prijavama, tj. ozdravljenjima potkrijepljenima liječničkim nalazima. Među slučajevima za koje postoji priložena medicinska dokumentacija o izlječenju nalazi se nekoliko pojedinačnih slučajeva izlječenja od multiple skleroze (Diana Basile i Rita Klaus), sljepoće (Joelle Beuret), Crohnove bolesti (Davis Parkes), frakture stopala (Loretta Young), inoperabilnog tumora hipofize (Colleen Willard), tumora mozga (Vicka Ivanković, Giacomo Mattalia), terminalne faze tumora bubrega (Artie Boyle), bilateralnog retinoblastoma (Megan McMahon), hydrocefalusa internusa (Damir Ćorić), paralize (Thierry Du Bus De Warnaffe, Mayr-Harting Else i Agnes Heupel), stenoze transverzalnog kolona uzrokovane tumorom (Logo Antonio) i diseminiranog encefalomijelitisa (Iva Tole). Navedeni slučajevi uključuju stanja kod kojih sadašnjim znanjem medicine nije moguće objasniti razloge uočenog poboljšanja, naravno, ako se prethodno isključi pogrešno postavljena dijagnoza ${ }^{26,27}$. Prvi opisani slučaj čudesnog izlječenja u Međugorju odnosio se na izlječenje trogodišnjeg dječaka Danijela Šetke koji je bolovao od spastične hemipareze i epilepsije. Neki od dosjea bili su poslani na provjeru u Association medicale internationale de Lourdes, međutim iz literature je vidljivo da nijedan, uključujući i onaj najkompletniji (slučaj Diana Basile), nije bio prihvaćen, pri čemu razloge treba tražiti u nepotpunoj dokumentaciji, kao i prirodi same bolesti (multipla skleroza) koja je podložna spontanim remisijama ${ }^{28}$.

Međunarodna francusko-talijanska znanstveno-teološka komisija „o izvanrednim događajima koji se događaju u Međugorju“ u vezi s vidjeocima, koja se sastojala od 17 renomiranih prirodoznanstvenika, liječnika, psihijatara i teologa, došla je 1986. do zaključka da se na temelju psiholoških istraživanja kod svih i pojedinih vidjelaca može sa sigurnošću isključiti varka i prijevara. Nadalje, da se na temelju medicinskih ispitivanja, testova, kliničkih promatranja itd. za sve i pojedine vidjeoce može isključiti da je riječ o patološkim halucinacijama, da su te pojave mimo naravnog reda. Ispitivanja vidjelaca također je provela francuska ekipa stručnjaka. Ona je, služeći se najmodernijim aparatima i stručnim znanjem, ispitivala unutarnje reakcije vidjelaca prije, za vrijeme i poslije ukazanja te sinkronizaciju njihovih reakcija u očima, ušima, srcu i mozgu. Rezultati su te komisije bili vrlo značajni. Pokazali su da je objekt opažanja izvan vidjelaca i da je isključena svaka manipulacija izvana ili međusobni dogovor vidjelaca. Rezultati spomenute komisije potvrdili su zaključke međunarodne komisije i sa svoje strane dokazali da su ukazanja o kojima svjedoče vidjeoci fenomen koji nadilazi današnju znanost $\mathrm{i}$ da sve upućuje na neki drugi nivo zbivanja. U razdoblju od 17 godina, od početka njihovih iskustava u ukazanju, subjekti (vidjeoci) ne pokazuju nikakve patološke simptome kao smetnje transa, disocijativne smetnje i smetnje gubljenja stvarnosti. Svi su ispitivani subjekti međutim pokazivali simptome koji se odnose na reakcije opravdanoga stresa koji nastaje prevelikom egzogenom i endogenom emocionalnom stimulacijom kao posljedica svakidašnjeg života. Iz osobnih svjedočenja proizlazi da početno i naknadno promijenjeno stanje svijesti nastaje zbog neobičnih iskustava koje su oni sami prepoznali i definirali i još uvijek prepoznaju kao viđenje/ukazanje Gospe ${ }^{28}$. Prikupljanje dokumentacije o čudesnim ozdravljenjima podložno je osobnoj prijavi, tako da je broj prijavljenih slučajeva sigurno manji od mogućeg broja. Brojna su i duhovna ozdravljenja, koja pak nije moguće potkrijepiti dokazima, nego se očituju u svakodnevnome životu.

\section{Znanstvena istraživanja o povezanosti molitve i liječenja/ izlječenja}

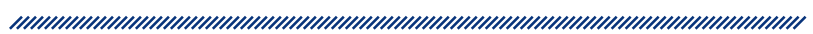

S obzirom na niz pojedinačnih opisanih slučajeva čudesnog ozdravljenja, ona predstavljaju izazov znanstvenicima u traženja dokaza koji mogu pružiti odgovor na pitanje utječu li zagovorničke molitve na povoljni ishod liječenja te mogu li se pojedini slučajevi objasniti medicinskim terminom spontane remisije. Polazna pretpostavka nekih istraživača glasi da je moguć pozitivan utjecaj zagovorničke molitve na izlječenje oboljelih, dok dio istraživača kritičkom analizom tih istraživanja ne nalazi opravdanja za prikazane rezultate ${ }^{29}$. Roberts i sur. $^{30}$ navode deset studija koje uključuju ukupno 7646 ispitanika, analizom kojih su zaključili da nema dokaza da molitva utječe na stopu morbiditeta umrlih od leukemije i kardiovaskularnih bolesti ( $n=1424$, OR 1,11, Cl 0,79 - 1,56), kao ni na smanjenje šanse za komplikacije nakon koronarnih kirurških zahvata $(n=1444$, OR $0,8, \mathrm{Cl}$ $0,64-1,00)$. Također se kroz četiri studije nije pokazalo da molitva utječe na smanjenje ponovnog prijema u koronarne jedinice $(n=2644$, $R R 1,00, C l 0,77-1,30)$ ili na rehospitalizaciju ( $n=1155$, OR 0,93, Cl 0,71-1,22). Rezultate koji bi dokazivali pozitivan učinak zagovorničke molitve ovi autori nisu potvrdili. 
Istovremeno Hobbings ${ }^{31}$ upozorava na niz etičkih propusta prilikom provođenja pokusa u kojem se provodi zagovornička molitva, dio kojih je povezan i s problemom informiranog pristanka pacijenta i kontradiktornošću pri dizajniranju istraživanja dvostrukoga slijepog pokusa kojim bi se provjeravao učinak zagovorničke molitve. Grupa skandinavskih autora, Jørgensen i sur. ${ }^{32}$, analizirajući deset radova o mogućem utjecaju molitve na zdravlje onih za koje se moli utvrdila je da nijedan od analiziranih radova ne zadovoljava kriterije sistemske analize potrebne za objavljivanje u bazama podataka Cochraine.

Nasuprot tome, istraživanja liječnika Byrda ${ }^{33}$ iz 1988. potvrđuju pozitivnu povezanost molitve i zdravstvenog stanja pacijenata. On je na slučajnom, dvostruko slijepom uzorku pokušao utvrditi hoće li molitva na daljinu imati ikakvog utjecaja na pacijente na odjelu za srčane bolesti. U navedenom su istraživanju 393 pacijenta bila podijeljena u dvije grupe. Za jednu je grupu bez njihova znanja molila kršćanska molitvena skupina izvan bolnice, a druga je bila kontrolna skupina. Svi su pacijenti bili pregledani i nije bilo statistički značajnih razlika u njihovu stanju prije liječenja. Istraživanje je trajalo 10 mjeseci. Nakon tretmana oni za koje se molilo imali su znatno blaže simptome i manje slučajeva pneumonije te su im rjeđe bili potrebni antibiotici i respirator u odnosu na pacijente za koje se nije molilo. U zaključku rada navedeno je da zagovorničke molitve imaju koristan terapeutski učinak.

Studija autora Roberts i sur. ${ }^{30}$ ukazala je na pozitivne učinke medicinski potpomognute oplodnje (engl. in-vitro fertilisation - IVF) kod onih grupa ispitanika koji su osobno molili u odnosu na grupu ispitanika koji nisu molili ( $n=169$, RR 0,68, Cl 0,53-0,86). Nadalje, Coruh i sur. ${ }^{34}$ donose sistemsku analizu radova u periodu od 1999. do 2003. na temelju kojih izvode zaključak da duhovna intervencija poput molitve ne samo da povećava uspjeh kod medicinsko potpomognute oplodnje (IVF) nego i smanjuje duljinu hospitalizacije i duljinu trajanja povišene temperature kod pacijenata sa sepsom, unaprjeđuje funkciju imunološkog sustava, poboljšava ishod kod reumatoidnog artritisa, smanjuje komplikacije i negativan ishod kod oboljelih od kardiovaskularnih bolesti i smanjuje anksioznost. Učestalost prisustvovanja vjerskim obredima unaprjeđuje zdravstveno ponašanje i smanjuje loš ishod kod oboljelih od kardiovaskularnih bolesti. Analizom literature objavljene u bazi Medline od 1966. do 1999. ${ }^{35}$ utvrdili su da randomizirani klinički pokusi potvrđuju pozitivan učinak molitve na ishod zdravlja pacijenata primljenih na koronarne odjele, ali ne potvrđuju učinak na stopu alkoholizma. Analizom nerandomiziranih kliničkih pokusa ustanovili su pozitivne učinke molitve na smanjenje krvnog tlaka, depresiju i funkciju imunološkog sustava.

Palmer i sur. ${ }^{36}$ objavili su rezultate kontroliranoga randomiziranog kliničkog pokusa istraživanja učinka zagovorničke molitve na grupu od 45 pacijenta, koji je pokazao da nije bilo značajnijeg pozitivnog učinka na grupu ispitanika u odnosu na 41 pacijenta u kontrolnoj grupi koji nisu znali da se za njih provodi zagovorničko moljenje, osim vrlo marginalnog efekta smanjenja boli među pacijentima za čije se zdravlje molilo. Kad se provela dodatna stratifikacija prema kriteriju vjere pacijenata u mogućnost izlječenja, među onima koji su imali pozitivan odnos i vjeru u svoje izlječenje zabilježen je pozitivan analgetski učinak u odnosu na one koji nisu imali vjere u mogućnost vlastitog izlječenja, čiji se rezultat nije znatnije razlikovao od kontrolne skupine. Nadalje, Hollywell i sur. ${ }^{37}$ objavili su podatke da je učinak osobne molitve bolesnika u obliku dijaloga s Bogom u pravilu povezan sa smanjenjem anksioznosti i depresije.

Istovremeno se čudesna ozdravljenja mnogo češće opisuju u medicinskoj znanstvenoj literaturi pod terminom „spontana remisija." Muzur ${ }^{38}$ smatra da je moguće prihvatiti znak jednakosti između jednih i drugih, podupirući tezu brojnim dokazima kroz povijest s opisima nepotpunih ili neuspjelih izlječenja, relapsa ili remisija bolesti i sličnog, smatrajući da je većina čudesnih izlječenja, kao i spontanih remisija, uzrokovanih sugestivnim mehanizmom. Pretragom baza podataka Pubmed i Medline pronalazi se oko 3000 opisanih slučajeva oporavaka, nerijetko i od izrazito teških stanja poput melanoma s metastazama, neuroblastoma, limfoma, multiple skleroze itd., pri čemu se u medicinskoj literaturi primjenjuje termin „spontana remisija“. Primjerice, Zahl i sur. ${ }^{39}$ donose rezultate studije koja pokazuje da prema nalazima mamografije $22 \%$ tumora dojke prolazi kroz fazu spontane remisije. Također, brojna su istraživanja potvrdila slučajeve spontane remisije bolesti kod različitih vrsta malignih bolesti. Fauvet ${ }^{40}$ je u razdoblju od 1960. do 1964. opisao 202 slučaja, dok je Boyd ${ }^{41}$ opisao još 98 slučajeva. Cole i sur. ${ }^{42}$ evidentirali su 176 slučajeva u razdoblju od 1900. do 1960., a Challis i sur. ${ }^{43}$ pronašli su 489 slučajeva spontane remisije u razdoblju od 1900. do 1987.

Procjenjuje se da je incidencija spontanih remisija $1 / 100000$, pri čemu je stvarni broj vjerojatno podcijenjen ${ }^{44}$. U većini opisanih slučajeva spontane remisije nije posebno proučavan faktor religioznosti i molitve za izlječenje kao mogući uzročnik zabilježenog poboljšanja pacijentova stanja te nije moguće jednom metaanalizom obuhvatiti jednu i drugu opisanu grupu radova. 
Dokumentiranje slučajeva ozdravljenja, neovisno o uzroku, ostavlja nadu svim oboljelima da bolest ne mora značiti i kraj i beznadnost, jer postoje brojni dokumentirani slučajevi koji potvrđuju opravdanost nade i vjeru u suprotno, čak i kad je medicina naizgled rekla zadnju riječ i priznala nemoć. Ako se izlječenja događaju direktnim uplivom Božje sile, tada će mehanizam njihova nastanka ostati nespoznatljiv, što ne obezvrjeđuje napore znanstvenika poput Levina ${ }^{1}$ da izlječenja pokušaju objasniti jednom od pet paradigmi: bihevioralno-kognitivnom, interpersonalnom, kognitivnom, afektivnom i psihofiziološkom odnosno psihoneuroimunološkom. Konačno, nemogućnost postojećih paradigmi da objasni fenomene izlječenja ili remisije njih same ne negira, već prije opravdava potrebu daljnjih istraživanja.

\section{Zaključak}

$\mathrm{Na}$ temelju raspoloživih rezultata dosad provedenih istraživanja nije moguće donijeti zaključak koji bi išao u smjeru potvrđivanja ili odbacivanja mogućeg utjecaja zagovorničke molitve na ishod liječenja, iako je znatno više studija koji takvu vezu ne dokazuju, pogotovo među onima koje su provedene po metodologiji kontroliranoga kliničkog pokusa. Međutim, značajni pozitivni ishodi među ispitanicima koji su sami aktivno molili za svoje zdravlje, od smanjenja komplikacija liječenja do smanjenja letalnih ishoda, upućuju na to da molitva i duhovnost imaju svoje mjesto u integriranoj skrbi za pacijenata kao tjelesnom, ali i duševnom i duhovnom biću. Istovremeno, pojedinačni slučajevi čudesnog izlječenja među hodočasnicima ili među osobama koje su osobno intenzivno molile za vlastito izlječenje, ponajprije u Lourdesu i Međugorju, upućuju na to da je s medicinskog aspekta riječ o vrlo zanimljivom fenomenu čije pomno znanstveno istraživanje ima svoju vrijednost. Pri tome se treba usmjeravati prema evaluaciji pozitivnog medicinskog učinka, bez potrebe da se donose zaključci o postojanju ili nepostojanju izravnog upliva Božje ili nadnaravne sile čije postojanje ostaje s one strane spoznatljivosti. Budući da je riječ o individualnom religijskom iskustvu svakog pojedinog pacijenta, molitva se nikad neće moći propisivati niti će se njome moći zamijeniti medicinska terapija ${ }^{45}$, no duhovni aspekt izlječenja treba uvažavati kao važan u cjelokupnom procesu integrativnog liječenja.

\section{Literatura}

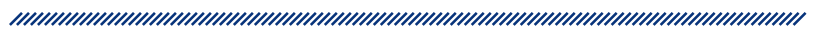

1. Levin J. How faith heals: a theoretical model, Explore. 2009; 5 (2):77-96.

2. Vukušić H. Duhovnost i medicina. U: Jurčić M, Nikić M, Vukušić H, ur. Vjera i zdravlje: Zbornik radova s interdisciplinarnog, multikonfesionalnog i internacionalnog simpozija održanog 2. ožujka 2005. godine na Filozofskom fakultetu Družbe Isusove u Zagrebu. 2. prošireno izd. Zagreb: Zaklada biskup Josip Lang; 2007. str. 3-20.

3. Ljubičić Đ. Duhovnost i psihijatrija. Rijeka: Sveučilište u Rijeci - Medicinski fakultet; 2009. str. 23.

4. Parlov M. Marulić: molitelj i učitelj molitve. Colloquia Maruliana. 2008:17;199-218.

5. Marinović Bobinac A. Dimenzije religioznog iskustva u Hrvatskoj: „šapat anđela“ iz sociologijske perspektive. Sociologija sela. 2005;168 (2);339-371.

6. Ameling A. Prayer: An ancient healing practice becomes new again. Holistic Nursing Practice. 2000;14 (3);40-48.

7. Bishop F, Yardley L, Lewith G. Treat or treatment: A qualitative study analyzing patients' use of complementary and alternative medicine. American Journal of Public Health. 2008;98:1700-1705.

8. Lugo L, Stencel S, Green J, et al. U.S. religious landscape survey; religious beliefs and practices: Diverse and politically relevant. U: Miller T, ur. The Pew Forum on Religion \& Public Life. Washington, DC: Pew Research Center; 2008. str. 276.

9. Tippens K, Marsman K, Zwickey H. Is prayer CAM? Journal of Alternative and Complementary Medicine. 2009;15(4):435438.

10. Kaptchuk TJ, Eisenberg DM. Varieties of healing. A taxonomy of unconventional healing practices. Annals of Internal Medicine. 2001;135:196-204.

11. Barnes P, Powell-Griner E, McFann K, Nahin LR. Complementary and alternative medicine use among adults: United States. Advance Data. 2004;27:1-19.

12. Pawlikowski J, Wiechetek M, Sak J, Jarosz M. Beliefs in Miraculous Healings, Religiosity and Meaning in Life. Religions. 2015;6:1113-1124.

13. Šetka J. Hrvatska kršćanska terminologija. II. izmijenjeno, popravljeno i upotpunjeno izdanje. Split: Reprint;1976. str. 60.

14. Levine M. Miracles. U: Zalta EN, ur. Stanford Encyclopedia of Philosophy. Stanford: Stanford Online Media; 2002. Dostupno na: http://plato.stanford.edu/entries/miracles/ (pristupljeno 20.04.2015.)

15. Stempsey WE. Miracles and the limits of medical knowledge. Medicine, Health Care and Philosophy. 2002;5(1):1-9.

16. Rebić A, Fućak J, Duda B, ur. Jeruzalemska Biblija. Zagreb: Kršćanska sadašnjost; 1996.

17. Duffin J. The doctor was surprised; or, how to diagnose a miracle. Bulletin of the History of Medicine. 2007;81(4):699729. 
18. Cerný K. Diagnosis of miracle or miraculous diagnosis? Comments on early modern understanding of unnaturalness. Prague Medical Report. 2009;110(2):128-39.

19. Woodward K. Making Saints: How the Catholic Church Determines Who Becomes a Saint, Who Doesn't, and Why. New York: Touchstone; 1996. str. 191-220.

20. Anonimus. Miracle attributed to John Paul II involved Parkinson's disease" Catholic World News (CWN). (c) 2009 Trinity Communications. January 30, 2006. Dostupno na: http://www.catholicculture.org/news/features/index.cfm?recnum=42131. (pristupljeno 11.01.2009.)

21. Skrabanek P. Paranormal health claims. Experientia.1988;15;44(4):303-309.

22. Norheim AJ. Miraculous cure in Lourdes? Tidsskriftet. 2009;129:1902.

23. Leven $\mathrm{KH}$. Our God rightly sends miracles only extremely rarely--Bernadette Soubirous (1844-1879), Lourdes, and the history of miracle cures. Praxis. 2006;95(41):1605-8.

24. Szabo J. Seeing is believing? The form and substance of French medical debates over Lourdes. Bulletin of the History of Medicine. 2002;76(2):199-230.

25. Kuner N. Miracles in dermatology? An overview of miraculous cures of skin diseases in the Catholic Church. Hautarzt. 2003;54(12):1203-6.

26. Sullivan R. The Miracle Detectives. Atlantic Monthly Press. 2004.

27. Dinolfo J. A Place of Healing, The Virgin Mary at Medjugorje. Ave Maria Centre of Peace. 2001.

28. Joyeux J, Laurentin H. Etudes medicales et scientifiques sur les apparitions de Međugorje. Paris; 1986.

29. Bonilla E. Mind-body connection, parapsychological phenomena and spiritual healing. A review. Investigación Clínica. 2010;51(2):209-238.

30. Roberts L, Ahmed I, Hall S, Davison A. Intercessory prayer for the alleviation of ill health. Cochrane Database of Systematic Reviews. 2009;2:CD000368. doi: 10.1002/14651858.CD000368.pub3

31. Hobbins PG. Compromised ethical principles in randomised clinical trials of distant, intercessory prayer. Journal of Bioethical Inquiry. 2005;2(3):142-52.

32. Jørgensen KJ, Hróbjartsson A, Gøtzsche PC. Divine intervention? A Cochrane review on intercessory prayer gone beyond science and reason. Journal of Negative Results in BioMedicine. 2009;8:7.

33. Byord RC. Positive therapeutic effect of intercessory prayer in a coronary care unit population. Southern Medical Journal. 1988;81(7):826 - 829.

34. Coruh B, Ayele H, Pugh M, Mulligan T. Does religious activity improve health outcomes? A critical review of the recent literature. Explore (NY). 2005;1(3):186-191.

35. Townsend M, Kladder V, Ayele H, Mulligan T. Systematic review of clinical trials examining the effects of religion on health. Southern Medical Journal. 2002;95(12):1429-34.

36. Palmer RF, Katerndahl D, Morgan-Kidd J. A randomized trial of the effects of remote intercessory prayer: interactions with personal beliefs on problem-specific out- comes and functional status. Journal of Alternative and Complementary Medicine. 2004;10(3):438-448.

37. Hollywell C, Walker J. Private prayer as a suitable intervention for hospitalised patients: a critical review of the literature. Journal of Clinical Nursing. 2009;18(5):637-651.

38. Muzur A. Saints, miracles and healings: eternal challenges. Vesalius. 1998;4(2):63-68.

39. Zahl PH, Mæhlen J, Welch HG. The Natural History of Invasive Breast Cancers Detected by Screening Mammography. Archives of Internal Medicine. 2008;168(21):2311-6.

40. Fauvet J. Spontaneous cancer cures and regressions. La Revue du praticien.1964;14:2177-2180.

41. Boyd W. The spontaneous regression of cancer. Springfield Il: Charles Thomas, Publ.; 1966

42. Cole WH. Spontaneous regression of cancer and the importance of finding its cause. National Cancer Institute monograph. 1976;44:5-9.

43. Challis GB, Stam HJ. The spontaneous regression of cancer. A review of cases from 1900. - 1987. Acta Oncologica. 1990;29(5):545-550.

44. Hirshberg C, O'Regan B. Spontaneous Remission. An Annotated Bibliography. Sausalito, Ca: Institute of Noetic Sciences; 1993.

45. Jantos M, Kiat H. Prayer as medicine: how much have we learned? Medical Journal of Australia. 2007;186 (10 Suppl):51-53. 


\section{THE SPIRITUAL SIDE OF HEALING - A SUPERNATURAL MIRACLE OR SPONTANEOUS REMISSION}

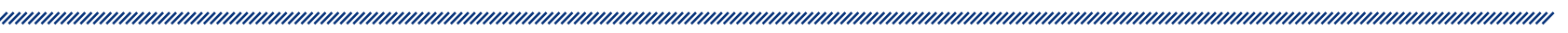

\author{
1 Aleksandar Racz \\ 1 Jadranka Pavić \\ 2 Vlado Čutura \\ 1 University of Applied Health Sciences Zagreb \\ 2 Glas Koncila
}

\section{Abstract

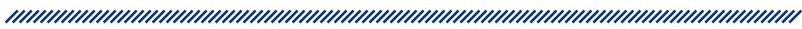

The paper focuses on examples of the spiritual side of healing for which there are different scientist approaches in providing explanation for sudden healing and influence of prayer on illness outcomes. Miraculous healings are a challenge for scientists in search of evidence which can provide the answer to the question whether intercessory prayer influences the favorable treatment outcomes, and whether individual cases can be explained through the use of the medical term spontaneous remission.

The initial assumption of some scientists is that the positive impact of intercessory prayer on patient cure is possible while some scientists through their critical analysis find no justification for the given results. Based on available results of the research so far it is not possible to reach a conclusion that would confirm or reject the potential impact of intercessory prayer on treatment outcome, even though there is a significantly higher number of studies that do not confirm such correlation, especially among those that have been conducted according to controlled clinical trials methodology.
However, there is ample evidence of positive outcomes among respondents who actively prayed for their health - outcomes ranging from reducing the incidence of treatment complications to reducing the incidence of lethal outcomes. The results indicate that prayer and spirituality have their own place in integrated care for patients as physical beings, but also as mental and spiritual beings.

At the same time, individual cases of miraculous healing among the pilgrims or among people who intensively prayed for the restoration of their health, especially at Lourdes and Međugorje, indicate that from a medical standpoint this is a very interesting phenomenon the thorough scientific research of which has its own value.

Keywords: miraculous healing, spirituality, healing through prayer 